\title{
1985 Essex Scholarships
}

The Canadian Political Science Association hopes again to receive a grant from the Social Sciences and Humanities Research Council of Canada to permit three Canadian members to attend the Summer School in Social Science Data Analysis and Collection held each year at The University of Essex, Colchester, England. The course is sponsored by The Department of Government at Essex and by the European Consortium for Political Research. It is very highly regarded and is attended by Western Europeans and some North Americans.

The Association offers three scholarships, of slightly in excess of $\$ 2,000$ each, to defray the cost of travel, fees and accommodation for the obligatory four-week stay. The programme takes place in July and August of each year.

The selection committee prefers evidence of a commitment to the political science profession. In practice this would mean that scholarship holders be professors, or students in their doctoral programme, or beyond.

We invite enquiries and will provide those interested with specific information on how to make a formal application. Please write, by February 28, 1985, to The Secretary-Treasurer, Canadian Political Science Association, University of Ottawa, Ottawa, Canada KIN 6N5.

\section{Bourses d'Études 1985 à The University of Essex}

L'Association canadienne de science politique espère recevoir encore une subvention du Conseil de recherches en sciences humaines du Canada pour permettre à trois de ses membres canadiens de participer au séminaire d'été de The University of Essex à Colchester, Angleterre (The Essex Summer School in Social Science Data Analysis and Collection). Ce séminaire est copatronné par The Department of Government à The University of Essex et « The European Consortium for Political Research ». Participent à ce seminaire de haut niveau des chercheurs venus d'Europe occidentale et d'Amérique du Nord.

L'Association offre trois bourses d'environ $2000 \$$ destinés à defrayer le coût du voyage, les frais d'inscription, et le logement pour un séjour obligatoire de quatre semaines. Le séminaire a lieu chaque année en juillet-août.

Le comité de sélection accordera la préférence aux étudiant(e)s au moins inscrit(e)s dans leur programme de doctorat, ou aux professeurs.

Pour tout renseignement, écrire avant le 28 fevrier 1985 au Secrétaire-trésorier, Association canadienne de science politique, Université d'Ottawa, Ottawa, Canada KIN 6N5. 